\title{
Metagenomic analysis of basal ice from an Alaskan glacier
}

\author{
Masood ur Rehman Kayani ${ }^{1 \dagger}$, Shawn M. Doyle ${ }^{2 \dagger}$, Naseer Sangwan ${ }^{3,4}$, Guanqun Wang ${ }^{1}$, Jack A. Gilbert ${ }^{3,4,5^{*}}$, \\ Brent C. Christner ${ }^{6 *}$ and Ting F. Zhu ${ }^{1 *}$
}

\begin{abstract}
Background: Glaciers cover 10\% of land but are among the least explored environments on Earth. The basal portion of glaciers often harbors unique aquatic microbial ecosystems in the absence of sunlight, and knowledge on the microbial community structures and their metabolic potential is very limited. Here, we provide insights into the microbial lifestyle present at the base of the Matanuska Glacier, Alaska.

Results: DNA and RNA were extracted from samples of the Matanuska Glacier basal ice. Using Illumina MiSeq and HiSeq sequencing, we investigated the microbial diversity with the metagenomic shotgun reads and $16 \mathrm{~S}$ ribosomal RNA data. We further assembled 9 partial and draft bacterial genomes from the metagenomic assembly, and identified key metabolic pathways such as sulfur oxidation and nitrification. Collectively, our analyses suggest a prevalence of lithotrophic and heterotrophic metabolisms in the subglacial microbiome.

Conclusion: Our results present the first metagenomic assembly and bacterial draft genomes for a subglacial environment. These results extend our understanding of the chemical and biological processes in subglacial environments critically influenced by global climate change.
\end{abstract}

Keywords: Microbiome, Metagenomics, Glacier, Basal ice layer

\section{Background}

Subglacial ecosystems are associated with hydrological networks at the base of glaciers and ice sheets that transport water discharged proglacially or into the ocean [1]. The role of glaciated environments in effecting the biogeochemistry of downstream ecosystems has only recently been appreciated [2]. Functional microbial ecosystems have been documented within subglacial aquatic environments in a range of alpine and valley glaciers [3], as well as beneath the Antarctic and Greenland ice sheets [4-7]. However, given the difficulty in accessing

\footnotetext{
*Correspondence: gilbertjack@uchicago.edu; xner@ufl.edu;

tzhu@tsinghua.edu.cn

${ }^{+}$Masood ur Rehman Kayani and Shawn M. Doyle contributed equally to this work.

${ }^{3}$ Biosciences Division (BIO), Argonne National Laboratory, 9700 South Cass

Avenue, Argonne, IL 60439, USA

${ }^{6}$ Department of Microbiology and Cell Science, Biodiversity Institute, University of Florida, Gainesville, FL 32611, USA

${ }^{1}$ School of Life Sciences, Tsinghua-Peking Joint Center for Life Sciences, Center for Synthetic and Systems Biology, Ministry of Education Key Laboratory of Bioinformatics, Tsinghua University, Beijing 100084, China Full list of author information is available at the end of the article
}

these environments, our understanding of microbial life in the ecosystems remains very limited.

Basal ice forms in the deepest portion of a glacier where the ice is in direct contact with the underlying bedrock, and its composition and structure become altered through interactions with glacier bed [8]. Basal processes such as localized pressure-induced melt-refreezing $[9,10]$ or glaciohydraulic supercooling [11] can capture materials (i.e., water and sediments) from the subglacial environment and transport them within the basal ice layer. Microorganisms that are associated with subglacial water and sediment become entrained in the basal ice layer together with nutrients important to supporting ecological processes within the subglacial environment $[8,12]$.

The Matanuska Glacier is a large, terrestrial valley glacier located in the Chugach Mountains of Southcentral Alaska, approximately $138 \mathrm{~km}$ north of Anchorage. It flows north $\sim 45 \mathrm{~km}$ from the Ted Stevens Ice Field and ranges in width from $\sim 3 \mathrm{~km}$ near the equilibrium line to $\sim 5 \mathrm{~km}$ along its terminus [13]. A number of hydrological, geochemical, and glaciological studies have been conducted on the Matanuska Glacier [11, 14-16] partly 
due to observations of supercooled subglacial water which emerges through vents, conduits, and crevasses at the terminus $[11,17,18]$. This meltwater produces frazil ice that can accrete, forming a debris-laden basal zone. Sediments within the subglacial discharge and entrained in basal ice are derived from Lower Cretaceous to Upper Jurassic (flysh, greenstone, limestone, chert, granodiorite, glaucophane-bearing greenshist, and layered gabbro and serpentinite), and Cretaceous to Upper Jurassic (graywacke, slate, argillite, volcanic detritus, and interbedded mafic) rocks.

In this study, we examined the microbial community inhabiting the basal ice layer from Matanuska Glacier, Alaska, using 16S rRNA gene (rDNA), 16S rRNA transcript (rRNA), and metagenomic sequencing analysis. These data were used to assemble 9 partial and draft bacterial genomes de novo and to assess the metabolic activity of specific microbial taxa based on $16 \mathrm{~S}$ rRNA to rDNA ratios.

\section{Methods}

Samples of exposed basal ice at the terminus of the Matanuska Glacier (Additional file 1: Figure S1) were collected in July 2013 using an electric chainsaw (61.776 N 147.761 W, 510-m elevation). The glaciological and physical properties of the basal ice at the Matanuska Glacier have been described previously [11]. Following sample decontamination as described previously [12], nucleic acids were extracted (see Additional file 1: Supplementary Methods). The Illumina MiSeq platform (Illumina, CA, USA) was used to perform 16S rRNA/ rDNA sequencing with paired-end read length of $250 \mathrm{bp}$ (see Additional file 1: Supplementary Methods). Sequences were clustered as operational taxonomic units (OTU) at 3\% dissimilarity using the furthest neighbor algorithm and classified using a naïve Bayesian classifier and the Ribosomal Database Project training set (Release 9). Representative sequences for each OTU were taxonomically classified using Greengenes (v123), SILVA (v13_5), and NCBI GenBank (Release 221). The metagenomic shotgun library was sequenced using an Illumina HiSeq 2500 system and read length of $150 \mathrm{bp}$. To assess taxonomic diversity of the metagenome, the paired-end reads were analyzed using Phylosift v1.0.1. The draft genomes were obtained using MetaBAT v2.12 after assembling the raw reads using the Iterative De-Bruijn Graph de novo assembler (IDBA-UD). Their completeness levels were assessed using CheckM (v0.9.7) while the functional annotations were performed using rapid annotation using subsystem technology (RAST) and KEGG automatic annotation server (KAAS) servers (see Additional file 1: Supplementary Methods).

\section{Initial findings}

The 16S rRNA and rDNA sequencing data revealed 2122 curated OTUs, with low microbial diversity (Inverse Simpson $=20.2$ and 4.2, respectively) (Additional file 1: Table S1) and high Good's coverage values ( $\geq 99.8 \%)$. Based on the rDNA sequencing data, the microbial community was dominated by bacteria (2091 OTUs) that included families such as Nitrospiraceae and Gallionellaceae (Fig. 1a). In contrast, the Desulfobulbaceae and Comamonadaceae families were of the highest abundance based on the $16 \mathrm{~S}$ rRNA sequencing data (Fig. 1b). To identify microbial community members that could be metabolically active [19], ratios of $16 \mathrm{~S}$ rRNA:rDNA relative abundance were calculated, the results of which showed that six OTUs had rRNA to rDNA ratios $>5$, including members of the Desulfobulbaceae, Syntrophaceae (Fig. 1c, Additional file 1: Table S2 and Additional file 2: Table S3).

The metagenomic sequencing data produced taxonomic classification results similar to the $16 \mathrm{~S}$ rRNA data, with bacteria dominating the microbial community and high abundances of Comamonadaceae, Hydrogenophilaceae, and other families (Fig. 1d). Methanogens have been documented previously in subglacial environments $[5,8]$; however, archaeal sequences were of low abundances in our basal ice metagenomic data $(0.2 \%)$, and $\sim 1.5 \%$ of the OTUs in $16 \mathrm{~S}$ rDNA library were classified as archaea.

Assembly of the metagenomic sequencing data allowed the recovery of 9 partial and draft genomes (further referred as Genome Bins (GBs)) with a completion level $\geq 70 \%$ and contamination level $\leq 10 \%$ (Fig. 1e, Additional file 2: Tables S4-S5). These GBs were classified within the genera Anaerolinea (Bin 11 and Bin 33), Synthrophus (Bin 2732 and Bin 31), and Thiobacillus (Bin 04), whereas the other 4 (Bin 0236, Bin 0512, Bin 17, and Bin 24) were unclassifiable and only identified as bacteria. The genomic statistics (genome lengths, contigs, genes, N50, and \%GC, etc.) for the $9 \mathrm{GBs}$ are summarized in Additional file 1: Figures S2-S3 and Additional file 2: Table S6.

In the absence of light, chemolithotrophy may support biogeochemical processes in the subglacial environment [6, 20-22]. Analyte measurement from the Matanuska basal ice sample indicated high concentration of $\mathrm{SO}_{4}$ (4600 ppb) and relatively lower $\mathrm{NO}_{3}$ concentration (60 ppb). These measurements suggested that sulfate and nitrate reduction could also be prevalent in the basal ice of Matanuska Glacier. Functional analysis of the GBs identified components of lithotrophic pathways, but likely due to incompleteness, intact pathways within a single draft genome were not recovered. Dissimilatory adenylylsulfate reductases ( $a p r A$ and $a p r B$ ) and sulfur oxidizing $(\operatorname{sox} B)$ genes were present in Bin 04 (Table 1). The identification of the $s o x B$ gene suggested potential 


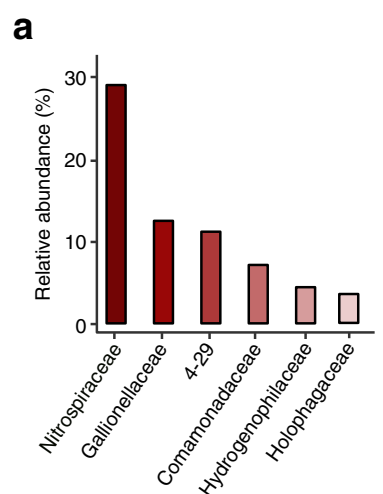

d

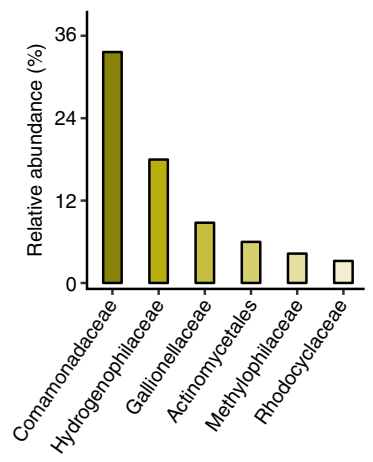

b

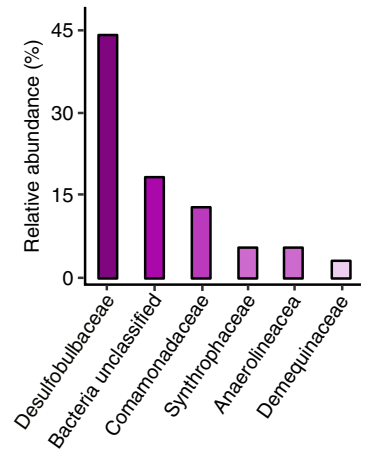

e
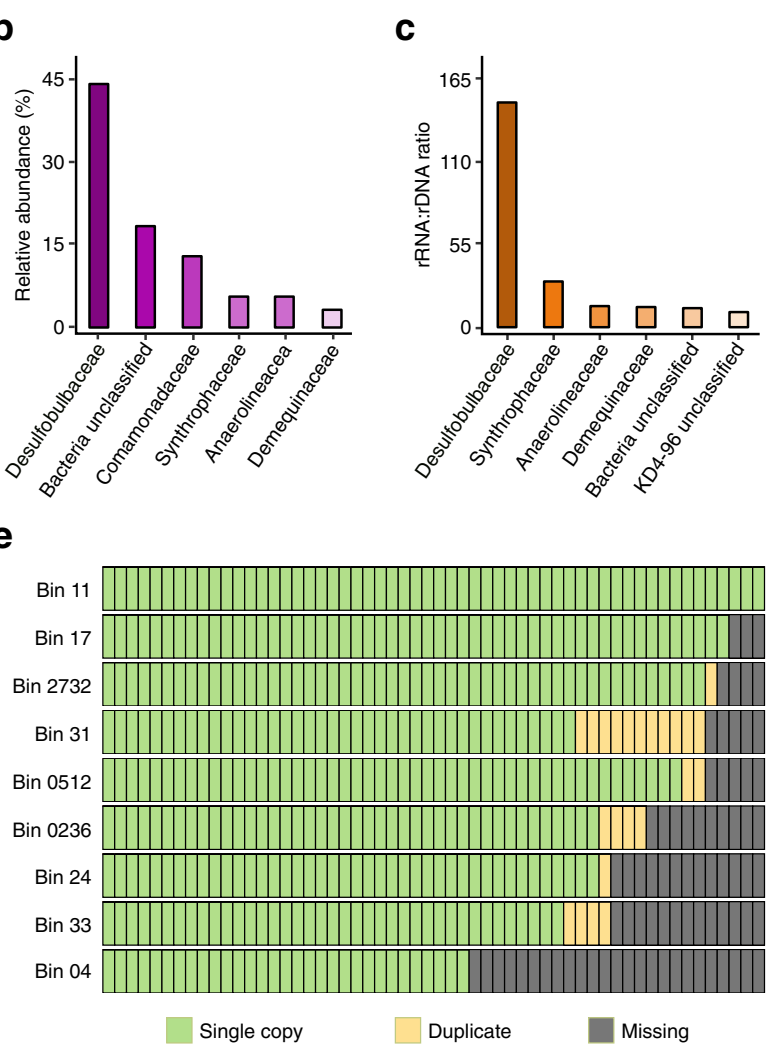

Fig. 1 Taxonomic classification, abundance, and genome binning of the Matanuska basal ice layer metagenome. Relative abundance of top bacterial families identified by 165 rDNA (a) and rRNA (b) sequencing data. c Top potential metabolically active bacterial OTUs inferred by rRNA to rDNA ratio. $\mathbf{d}$ Relative abundance of top bacterial families identified by metagenomic data. e Partial and draft genome quality assessment plot indicating completeness and contamination levels of each GB

for lithotrophic metabolism via oxidation of reduced sulfur compounds (e.g., hydrogen sulfide, sulfur, sulfite, and thiosulfate) for energy production. Furthermore, Bin 04 also possessed genes of dissimilatory nitrate reductases (narGHI and $n a p A)$ and nitrite oxidoreductase $(n x r A)$, implying the capability to utilize nitrate as terminal electron acceptor in anaerobic respiration. The presence or absence of key pathways and genes in the Matanuska basal ice layer GBs are summarized in Additional file 1: Figure S4 and Additional file 2: Tables S7-S9.

Genes of carbon metabolism pathways in the GBs were mostly involved in central carbohydrate metabolisms such as glycolysis, gluconeogenesis, and pyruvate metabolism (Additional file 2: Table S9). However, $\mathrm{CO}_{2}$ fixation enzymes, especially Ribulose bisphosphate carboxylase (RuBisCO), were also identified in Bin 04. The ability to perform $\mathrm{CO}_{2}$ fixation supports the hypothesis for microbial lithoautotrophic metabolism via sulfur oxidation. The GBs also contained genes related to cold and oxidative stress tolerance: Bin 11 and Bin 31 contained genes of cold shock protein $(\operatorname{csp} A)$, whereas Bin 04, Bin 0236, and Bin 2732 possessed genes of catalase and superoxide dismutase.

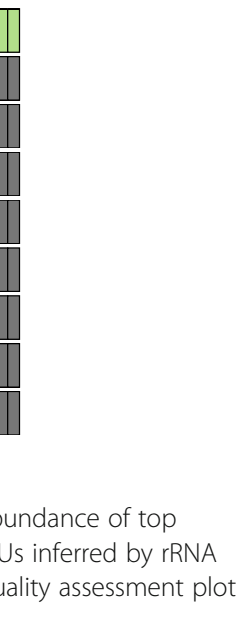

In summary, our $16 \mathrm{~S}$ rRNA/rDNA and metagenomic sequencing data suggested the presence of abundant bacterial taxa within the Matanuska basal ice layer, and functional predictions suggested the presence of genes involved in sulfur lithotrophy as well as nitrate/sulfate respiration.

\section{Future directions}

The current data presented a metagenomic shotgun analysis of a basal ice layer of glacier. The metagenomic assembly and draft genomes are, to the best of our knowledge, the only reference datasets currently available for a subglacial ecosystem, providing valuable insight into the biogeochemical potential of the microbial communities within these permanently frozen ecosystems. The inaccessibility of these environments remains a major hindrance, and a limitation of this study is that it represents a single basal ice cryofacies (i.e., dispersed ice) from a single glacier. More thorough sampling and analysis of multiple basal ice cryofacies (e.g., clean, banded, solid, and stratified) and different glacier types (i.e., cold, temperate, and polythermal) are necessary to establish a comprehensive understanding of the diversity and function of microbial communities 


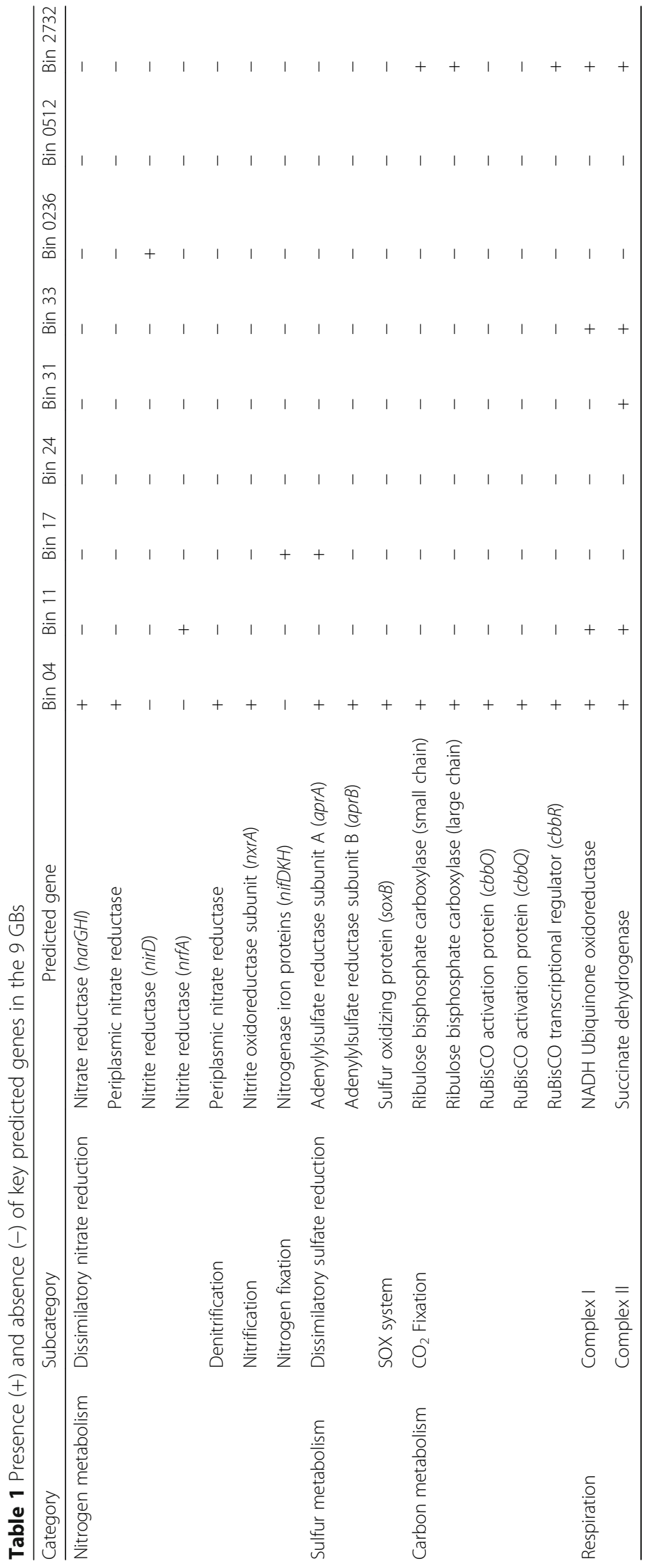


inhabiting the basal zones of glaciers. Despite the limitations, our results may be used in several downstream studies such as comparative analysis of the basal ice zones and other glacial environments. The draft genomes obtained by this study may also be important for comparative genomics and evolutionary studies.

\section{Additional files}

Additional file 1: Supplementary Information. (PDF $1581 \mathrm{~kb})$

Additional file 2: Supplementary Tables. (XLSX $142 \mathrm{~kb}$ )

\section{Acknowledgements}

We thank M. Beitch, K. Myers, S. Neuhaus, and S. Tulaczyk for assistance with sample collection; B. Hagedorn for site information and chemistry data; and L. Li for discussions on metagenomic data analysis. This work was supported in part by funding from the Ministry of Science and Technology of China (2016YFC0206300 and 2015CB553402), the National Natural Science Foundation of China (21750005, 31470532, 91543102, and 31711530153), the Beijing Nova Program (Z171100001117011), the Tsinghua University Initiative Scientific Research Program (20161080152), the NASA ASTEP Program (NNX11AJ89G), the Tsinghua University-Peking University Center for Life Sciences (CLS), and the Beijing Advanced Innovation Center for Structural Biology.

\section{Availability of data and materials}

The raw sequencing reads are available on the MG-RAST server with accession number mgm4745458.3. Amplicon data are available on the NCBI sequence read archive (SRA) under BioSample accession number SAMN03571257.

\section{Authors' contributions}

BCC collected the sample and SMD extracted nucleic acids. MRK, SMD, NS, and GW performed the sequencing and data analysis. JAG, BCC, and TFZ supervised the study. All authors read and approved the final manuscript.

\section{Competing interests}

The authors declare that they have no competing interests.

\section{Author details \\ 'School of Life Sciences, Tsinghua-Peking Joint Center for Life Sciences, Center for Synthetic and Systems Biology, Ministry of Education Key Laboratory of Bioinformatics, Tsinghua University, Beijing 100084, China. ${ }^{2}$ College of Geosciences, Texas A\&M University, College Station, TX 77843, USA. ${ }^{3}$ Biosciences Division (BIO), Argonne National Laboratory, 9700 South Cass Avenue, Argonne, IL 60439, USA. ${ }^{4}$ Department of Surgery, The Microbiome Center, University of Chicago, 5841 South Maryland Avenue, MC 5029, Chicago, IL 60637, USA. ${ }^{5}$ The Microbiome Center, Marine Biological Laboratory, 7 MBL Street, Woods Hole, MA 02543, USA. ${ }^{6}$ Department of Microbiology and Cell Science, Biodiversity Institute, University of Florida, Gainesville, FL 32611, USA.}

Received: 2 April 2018 Accepted: 18 June 2018

Published online: 05 July 2018

\section{References}

1. Horgan HJ, Alley RB, Christianson K, Jacobel RW, Anandakrishnan S, Muto A, Beem LH, Siegfried MR. Estuaries beneath ice sheets. Geology. 2013;41(11): 1159-62.

2. Wadham JL, Tranter M, Skidmore M, Hodson AJ, Priscu J, Lyons WB, Sharp M, Wynn P, Jackson M. Biogeochemical weathering under ice: size matters. Glob Biogeochem Cycles. 2010;24(3). https://doi.org/10.1029/2009GB003688.

3. Skidmore M. Microbial communities in Antarctic subglacial aquatic environments. In: Antarctic subglacial aquatic environments. Washington DC: American Geophysical Union; 2011. p. 61-81.
4. Achberger AM, Christner BC, Michaud AB, Priscu JC, Skidmore ML, VickMajors TJ. Microbial community structure of Subglacial Lake Whillans, West Antarctica. Front Microbiol. 2016;7:1457.

5. Achberger AM, Michaud AB, Vick-Majors TJ, Christner BC, Skidmore ML, Priscu JC, Tranter M. Microbiology of subglacial environments. In: Psychrophiles: from biodiversity to biotechnology. Cham: Springer; 2017. p. 83-110.

6. Christner BC, Priscu JC, Achberger AM, Barbante C, Carter SP, Christianson K, Michaud AB, Mikucki JA, Mitchell AC, Skidmore ML, et al. A microbial ecosystem beneath the West Antarctic ice sheet. Nature. 2014;512(7514): 310-3.

7. Dieser M, Broemsen EL, Cameron KA, King GM, Achberger A, Choquette K, Hagedorn B, Sletten R, Junge K, Christner BC. Molecular and biogeochemical evidence for methane cycling beneath the western margin of the Greenland ice sheet. ISME J. 2014;8(11):2305-16.

8. Montross S, Skidmore M, Christner B, Samyn D, Tison J-L, Lorrain R, Doyle S, Fitzsimons S. Debris-rich basal ice as a microbial habitat, Taylor Glacier, Antarctica. Geomicrobiol J. 2014;31(1):76-81.

9. Hubbard B, Sharp M. Basal ice formation and deformation: a review. Prog Phys Geogr. 1989;13(4):529-58.

10. Knight PG. The basal ice layer of glaciers and ice sheets. Quat Sci Rev. 1997; 16(9):975-93.

11. Lawson DE, Strabser JC, Evenson EB, Alley RB, Larson GJ, Arcone SA. Glaciohydraulic supercooling: a freeze-on mechanism to create stratified, debris-rich basal ice: I. Field evidence. J Glaciol. 1998;44(148):547-63.

12. Doyle SM, Montross SN, Skidmore ML, Christner BC. Characterizing microbial diversity and the potential for metabolic function at $-15{ }^{\circ} \mathrm{C}$ in the Basal Ice of Taylor Glacier, Antarctica. Biology. 2013;2(3):1034-53.

13. Lawson DE. A comparison of the pebble orientations in ice and deposits of the Matanuska Glacier, Alaska. J Geol. 1979;87(6):629-45.

14. Alley R, Lawson D, Larson G, Evenson E, Baker G. Stabilizing feedbacks in glacier-bed erosion. Nature. 2003;424(6950):758-60.

15. Ensminger SL, Alley RB, Evenson EB, Lawson DE, Larson GJ. Basal-crevasse-fill origin of laminated debris bands at Matanuska Glacier, Alaska, USA. J Glaciol. 2001:47(158):412-22.

16. Gulley J. Structural control of englacial conduits in the temperate Matanuska Glacier, Alaska, USA. J Glaciol. 2009:55(192):681-90.

17. Arcone SA, Lawson DE, Delaney AJ. Short-pulse radar wavelet recovery and resolution of dielectric contrasts within englacial and basal ice of Matanuska Glacier, Alaska, USA. J Glaciol. 1995;41(137):68-86.

18. Alley RB, Lawson DE, Evenson EB, Strasser JC, Larson GJ. Glaciohydraulic supercooling: a freeze-on mechanism to create stratified, debris-rich basal ice: II. Theory. J Glaciol. 1998;44(148):563-9.

19. Hirsch PR, Mauchline TH, Clark IM. Culture-independent molecular techniques for soil microbial ecology. Soil Biol Biochem. 2010;42(6):878-87.

20. Mitchell AC, Lafrenière MJ, Skidmore ML, Boyd ES. Influence of bedrock mineral composition on microbial diversity in a subglacial environment. Geology 2013:41(8):855-8.

21. Mikucki J, Lee P, Ghosh D, Purcell A, Mitchell A, Mankoff K, Fisher A, Tulaczyk S, Carter S, Siegfried M. Subglacial Lake Whillans microbial biogeochemistry: a synthesis of current knowledge. Phil Trans R Soc A. 2016;374(2059): 20140290.

22. Boyd ES, Hamilton TL, Havig JR, Skidmore ML, Shock EL. Chemolithotrophic primary production in a subglacial ecosystem. Appl Environ Microbiol. 2014; 80(19):6146-53.

\section{Ready to submit your research? Choose BMC and benefit from:}

- fast, convenient online submission

- thorough peer review by experienced researchers in your field

- rapid publication on acceptance

- support for research data, including large and complex data types

- gold Open Access which fosters wider collaboration and increased citations

- maximum visibility for your research: over $100 \mathrm{M}$ website views per year

At BMC, research is always in progress.

Learn more biomedcentral.com/submissions 